\title{
Importation of poliomyelitis to industrialised nations between 1975 and 1984: evaluation and conclusions for vaccination recommendations
}

\author{
DORIS KUBLI， ROBERT STEFFEN， MEINRAD SCHÄR
}

\begin{abstract}
World Health Organisation and public health authority records show that 175 cases of paralytic poliomyelitis were imported to industrialised countries between 1975 and 1984. Detailed case reports were therefore analysed to identify characteristic features associated with acquisition of the infection. Of the 175 cases, 96 $(55 \%)$ were diagnosed in foreign workers or their families, 47 $(27 \%)$ in nationals travelling on holiday or business, $11(6 \%)$ in immigrants, and $21(12 \%)$ either in contacts who had not travelled or in unclassified groups. Poliomyelitis principally affected children under 5 , but travellers aged 41-65 had the highest case fatality rate. The main serotype isolated was poliovirus type 1.

The findings suggest that though fewer than one in every 100000 travellers may be infected by poliomyelitis, all travellers and all immigrants, refugees, and foreign workers should be given full protection against all three polioviruses by routine vaccination.
\end{abstract}

\section{Introduction}

We have studied systematically infections acquired overseas that are potentially preventable by immunisation. ${ }^{1-5}$ In this final inquiry we address the problem of poliomyelitis acquired by travellers from industrialised countries who visit developing countries and additionally evaluate other imported cases.

Poliomyelitis is scarcely considered a threat to health for travellers by the general public and by large sections of the profession. Hence poliomyelitis vaccination is rarely recommended

\footnotetext{
Institute for Social and Preventive Medicine, University of Zurich, CH-8006 Zurich, Switzerland

DORIS KUBLI, MD, voluntary resident

ROBERT STEFFEN, MD, head, section for epidemiology and prevention of communicable diseases MEINRAD SCHÄR, MD, MPH, professor

Correspondence to: Dr Steffen.
}

in the medical section of travel brochures. The incidence of infection is still high in the Third World, however, and cases of paralytic illness in unprotected travellers have been reported..$^{6-15}$ This paper therefore investigates all cases of imported paralytic poliomyelitis recorded in industrialised nations in the decade 1975-84 in order to assess the magnitude of the problem and judge whether a change in vaccination recommendations is warranted.

\section{Methods}

The study was conducted as a retrospective epidemiological survey of paralytic poliomyelitis imported between 1975 and 1984. We invited all health authorities in Europe and other industrialised nations in North America (Canada, United States), Australasia (Australia, Japan, New Zealand, Singapore), and Africa (South Africa) to complete a questionnaire for each case of poliomyelitis that was imported from abroad during the study period. The questionnaire sought the following details: patient's age, sex, country of residence, nationality, profession, country visited, date and purpose of stay abroad, time of onset and duration of illness, serotype, symptoms, outcome, and poliomyelitis vaccination state. Of the 33 countries surveyed, only two (Bulgaria and Yugoslavia) failed to reply. The data were collated and checked against published cases, these sources frequently being supplied by the health authorities of the countries concerned. Any inconsistency in recorded data was clarified by correspondence.

Imported cases were separated into five categories:

(a) Travellers were citizens and residents of industrialised nations who had stayed abroad on holiday, to work, or on business.

(b) Immigrants were people from developing countries who had come to an industrialised nation as new immigrants, refugees, or children for adoption or children born in developing countries to citizens of industrialised countries.

(c) Foreign workers were citizens of developing countries who had stayed in industrialised nations as temporary residents. This group included members of their extended family on arrival or returining from home leave.

(d) Contacts were citizens of industrialised nations who had not travelled away from their home country but were presumed to have been infected by an imported case. Contact cases in foreign workers were included in category (c).

(e) Unclassified referred to people with incomplete data-for example, gypsies.

Patients who could not be traced were those treated in Third World countries exclusively. 
Results

Documentation was more or less complete in cases in travellers and contacts, but information on immigrants and foreign workers was often scarce, especially with respect to outcome, as these patients were often repatriated. A total of 175 patients were reported to have contracted poliomyelitis abroad or as a result of other people's travel. Overall, men were affected more often than women, but otherwise there were vast discrepancies among the categories (table).

Characteristics of cases of poliomyelitis imported to industrialised nations during 1975-84

\begin{tabular}{|c|c|c|c|c|c|c|}
\hline Characteristics & Travellers & $\begin{array}{l}\text { Foreign } \\
\text { workers }\end{array}$ & Immigrants & Contacts & $\begin{array}{l}\text { Unclassi- } \\
\text { fied }\end{array}$ & Total \\
\hline $\begin{array}{l}\text { Total patients } \\
\text { Age range }\end{array}$ & $\begin{array}{c}47 \\
6 \text { months to } \\
67 \text { years }\end{array}$ & $\begin{array}{c}96 \\
4 \text { months to } \\
35 \text { years }\end{array}$ & $\begin{array}{c}11 \\
4 \text { months to } \\
3 \text { years }\end{array}$ & $\begin{array}{c}18 \\
11 \text { months } \\
\text { to } 49 \text { years }\end{array}$ & $\begin{array}{c}3 \\
2 \text { years } \\
\text { to ? }\end{array}$ & $\begin{array}{c}175 \\
4 \text { months to } \\
67 \text { years }\end{array}$ \\
\hline $\begin{array}{l}\text { Mean/median } \\
\text { age }\end{array}$ & $\begin{array}{c}29 \cdot 3 / 26 \cdot 0 \\
\text { years }\end{array}$ & $\begin{array}{c}3 \cdot 5 / 2 \cdot 0 \\
\text { years }\end{array}$ & $\begin{array}{c}1.4 / 1 \cdot 0 \\
\text { year }\end{array}$ & $\begin{array}{c}16 \cdot 8 / 18 \cdot 0 \\
\text { years }\end{array}$ & & $\begin{array}{c}11 \cdot 4 / 2 \cdot 0 \\
\text { years }\end{array}$ \\
\hline $\begin{array}{l}\text { Sex }(\text { No }(\%)): \\
\text { Male } \\
\text { Female } \\
\text { Unknown }\end{array}$ & $\begin{array}{c}30(63 \cdot 8) \\
14(29 \cdot 8) \\
3(6 \cdot 4)\end{array}$ & $\begin{array}{l}\star *(65 \cdot 0) \\
\star(35 \cdot 0)\end{array}$ & $\begin{array}{l}7(63 \cdot 6) \\
2(18 \cdot 2) \\
2(18 \cdot 2)\end{array}$ & $\begin{array}{c}11(61 \cdot 1) \\
6(33 \cdot 3) \\
1(5 \cdot 6)\end{array}$ & $\begin{array}{l}0 \\
1(33 \cdot 3) \\
2(66 \cdot 7)\end{array}$ & M:F 2:1 \\
\hline Died & 7 & $?$ & $?$ & 0 & $?$ & $?$ \\
\hline $\begin{array}{l}\text { Source (region): } \\
\text { Africa } \\
\text { Asia (exclud- }\end{array}$ & 19 & 2 & 2 & 0 & 0 & 23 \\
\hline ing Turkey) & 9 & 0 & 7 & 0 & 0 & 16 \\
\hline Turkey & 3 & 84 & 0 & 0 & 0 & 87 \\
\hline Mexico & 11 & 0 & 1 & 0 & 0 & 12 \\
\hline South America & 4 & 0 & 0 & 0 & 0 & 4 \\
\hline Netherlands & 0 & 0 & 0 & 16 & 0 & 16 \\
\hline Europe & 0 & 10 & 0 & 0 & 1 & 11 \\
\hline Unknown & 1 & 0 & 1 & 2 & 2 & 6 \\
\hline
\end{tabular}

^Exact number unknown; proportion derived partly from German statistics for 1973-84.

\section{TRAVELLERS}

Of the 47 travellers reported to be infected, only 11 were children below 10 years of age and two aged between 11 and 20 . Of the remainder, 12 were aged 21-30, five aged $31-40$, and 16 over 40 . The age of one patient was not recorded. Nineteen of the travellers were on holiday and six visiting relatives or friends, six working abroad, and six on a business trip. The reason for travel in 10 patients was unknown. The duration of stay abroad varied from a few days to one month in 12 cases, was one month to a year in 10 , and exceeded one year in three cases; in the remainder the length of stay was unknown.

Twelve of the 47 travellers had received at least one dose of poliomyelitis vaccine, in seven cases oral vaccine and five intramuscular vaccine. In six of these patients the last dose of vaccine within a completed series had been given 16 or more years previously but none was known to have been given a booster dose. Two patients had received a single dose of oral vaccine only two and seven years previously, respectively. Two babies aged about 12 months had received two doses of oral vaccine several months previously, and one adult had obtained four doses of intramuscular vaccine between 1956 and 1959, followed by a booster dose intramuscularly in 1982, shortly before departure, which was six weeks before the first symptoms. In the 12th case details of vaccination could not be established. Twenty eight patients stated that they had not been vaccinated, and in the remaining seven the vaccination state was unknown.

Forty four patients remained in hospital for one to several months. This question was not answered in the other three cases. Severe paralysis persisted in 21 patients, minimal lesions in two, and a complete remission occurred in another two. Seven patients died after an illness ranging from six to 116 days. All deaths were in patients aged 44-63, which corresponds to a mortality of $46.6 \%$ in patients aged $41-65$. In 15 patients the outcome was unknown.

Over half of all cases of imported poliomyelitis in travellers were reported from the United States (11), the Federal Republic of Germany (10), and Great Britain (six). The remaining 20 cases were scattered among 10 other countries.

\section{FOREIGN WORKERS}

Ninety six cases were reported in foreign workers and their families. Of these patients, 94 were aged under 10 and 34 less than 1 year old. The vast majority were children of Turkish foreign workers who developed symptoms in the Federal Republic of Germany after having been infected during home leave. It is estimated that one third of the 96 patients contracted poliomyelitis in Germany from imported cases in the same family or from visiting asymptomatic relatives. ${ }^{15}$ Most other cases in this category originated from Greece, Yugoslavia, or north Africa. Reports ascertained that none of the 96 patients had been vaccinated against poliomyelitis, but no information was available on the outcome of the disease.

\section{IMMIGRANTS}

Seven of the 11 cases in immigrants were in small children of immigrants or refugees. Another patient was a child born in Mexico to an American citizen living there. The remaining three patients had come to industrialised countries for adoption. None of the patients had been vaccinated. Four remained paralysed, one recovered, and the outcome of the others was unknown. Four of the cases were detected in Scandinavia, the rest in Australia, Singapore, Spain, and the United States.

\section{CONTACTS}

Six of the 21 autochthonous cases occurred in Canadians who had been visited by Dutch friends. ${ }^{8}$ These contacts belonged to a religious group that refused all vaccinations. Two other patients were diagnosed, one as an asymptomatic excreter and one as a case of meningitis. It was proved that the same type 1 poliovirus had caused an epidemic outbreak in the Netherlands. In 1979 a further 10 cases were registered in the United States after introduction of the virus by members of the religious group through Canada. Additionally, one Australian baby was infected by a family who had just returned from an endemic area, and a Swiss taxi driver was thought to have been infected by one of his frequent customers, who came from an endemic area.

\section{SEROLOGY AND VIRUS ISOLATION}

In the travellers, foreign workers, and immigrant groups roughly half of the infections were due to poliovirus type 1 , one fifth to type 2 , one 10 th to type 3 , and less to mixed infections. In the remaining cases the serotype was unknown. In 24 patients this information was based only on isolation of the virus, in 13 on serology alone, and in another 20 on both methods.

\section{Discussion}

Retrospective surveys cannot confidently be used to determine values because of the uncertainty of completeness in ascertaining numerator data. Hence collection of data in our series was often incomplete with various important data missing. Similarly, the denominator can be estimated only very roughly. ${ }^{16}{ }^{17}$ Nevertheless, some conclusions may be made with respect to the magnitude of the problem.

The 175 cases of imported poliomyelitis represent $2 \cdot 9 \%$ of the 6030 cases of poliomyelitis that were reported to the World Health Organisation by industrialised nations during $1975-84 .{ }^{18}$ If we exclude cases from South Africa and the Soviet Union, which reported no imported cases but had many autochthonous cases, the proportion rises to $8 \cdot 7 \%$ of the remaining 2003 cases that occurred in the rest of the industrialised nations.

Paralytic poliomyelitis is rare in travellers. Anyone, not only children, may be affected after a few days abroad. Roughly 140 million travellers who were residents of industrialised nations had visited developing countries within the 10 years covered by the survey. ${ }^{16}{ }^{17}$ Of these, 47 acquired poliomyelitis. We may therefore deduce that only one in 3 million travellers will get paralytic poliomyelitis.

Asymptomatic infection, however, is much more frequent than paralysis. Given that only one in 22 to one in 1000 infected people have paralytic poliomyelitis, ${ }^{19-21}$ we must assume that within the 10 year period 1034 to 47000 travellers imported the infection and may have excreted the virus for several weeks. ${ }^{22}$ The incidence of infection per journey to developing countries may be estimated as 0.7 to $33 \cdot 6 / 100000$ travellers or one in 3000 to 135000 travellers. As 
a higher proportion of adults tend to have paralytic infections, we consider the lower incidence estimates to be more likely. Surprisingly, only 18 patients were reported in the contact group. This, however, may have been due to artefacts in reporting, possibly some health authorities failing to investigate this aspect thoroughly.

There was no definite failure of vaccination among the patients reviewed. The data suggest that two doses of oral vaccine given to babies a few weeks before departure are insufficient for complete protection and also that an intramuscular booster dose given after a protracted period (in this instance 23 years) will not raise a satisfactory antibody titre for a journey beginning a few days later.

In view of the potential danger to both the travellers, even if just a few, and people remaining at home poliomyelitis vaccination must remain a firm recommendation to all travellers visiting developing countries. Special emphasis must be placed on the appropriate vaccination of older travellers and no upper age limit should be set, as has been advocated. Even if the need for supplementary oral or intramuscular doses given after a completed series of vaccination is not established ${ }^{23}$ it may be good practice to give an additional booster if the last dose was more than five years previously. The poliovirus antibody state of most travellers is not known. Only $80 \%$ of Scottish tourists visiting Malta or Rumania were shown to possess antibody titres to all three serotypes. ${ }^{24}{ }^{25}$ No data about protection rates in travellers of other nations have been published to our knowledge.

Despite efforts by the WHO to promote the expanded programme on immunisation many citizens of developing countries are not immunised. Health authorities in industrialised countries who receive immigrants, refugees, and foreign workers from developing countries therefore need to ensure that poliomyelitis vaccination and revaccination schemes are available for all new arrivals and for those born in the host country.

We thank the authorities of the public health institutions of the 31 countries who made this survey possible. Ms Penelope Phillips-Howard and Dr Edward Brink contributed valuable advice. We are also grateful to Miss Elisabeth Vollenweider for secretarial help.

\section{References}

I Morger H, Steffen R, Schär M. Epidemiology of cholera in travellers and conclusions for vaccination recommendations. Br Med f 1983;286:184-6.

2 Steffen R, Boppart I. Traveller's diarrhoea. Clinical Gastroenterology (Baillière's) (in press).

3 Steffen R. Typhoid vaccine, for whom? Lancet 1982;i:615-6.

4 Apothéloz M, Grob PJ, Steffen R, Schär M. Welchen auslandreisenden ist ein impfschutz gegen hepatitis zu empfehlen? Soz Praventivmed 1982;27:264-5.

5 Steffen R, Schär G, Mosimann J. Salmonella and shigella infections in Switzerland, with special reference to typhoid vaccination for travellers. Scand J Infect Dis 1981;13:121-7.

6 Bell EJ, Riding MH, Grist NR. Paralytic poliomyelitis: a forgotten diagnosis? $\mathrm{Br}$ Med $\mathrm{J}$ 1986;293:193-4.

7 Centers for Disease Control. Poliomyelitis-United States. MMWR 1986;35: 180-2.

8 Furesz J. Poliomyelitis outbreaks in the Netherlands and Canada. Can Med Assoc $\mathcal{F}$ 1979;120: 905-6.

9 Krech U. Importierte viruskrankheiten. In: Gsell O, ed. Importierte infektionskrankheitenepidemiologie und therapie. 15. Symposium der Deutschen Geselschaft für Fortschritte auf dem Gebiet der Inneren Medizin. Stuttgart: Thieme, 1980.

10 Op de Coul AAW, Peeters MF. Een patient met een ernstige paralytische vorm van poliomyelitis na verblijf in Tunesie. Ned Tijdschr Geneeskd 1982;126:1054-5.

11 Pöhn HP. Epidemiologische situation in der Bundesrepublik Deutschland 1983. MMW 1984;126:1400-2.

12 Weise HJ, Pöhn HP. Epidemiologie der poliomyelitis in der Bundesrepublik Deutschland und Berlin (West) 1978 bis 1982. MMW 1984;126:269-74.

13 Weise HJ. Krankheitseinschleppungen in die Bundesrepublik Deutschland einschl Berlin (West) 1979-80. Bundesgesund heitsblatt 1981;24:241-50.

14 Weise HJ. Poliomyelitis in der Bundesrepublik Deutschland einschl Berlin (West) 1968-77. Bundesgesundheitsblatt 1978;21:121-8.

15 Willers H, Sipos S, Knocke KW. Epidemiologie der enterovirus-erkrankungen-einschliesslich poliomyelitis-in Niedersachsen 1983. Off Gesundheitswes 1984;46:187-9.

16 International Air Transport Association. World air transport statistics 1984. No. 29. Geneva: IATA, 1985.

17 World Tourism Organisation. World tourism development. Madrid: WTO, 1980. (BCT/3.)

18 World Health Organisation. Poliomyelitis. Weekly Epidemiological Record 1975-86.

19 Melnick JL, Ledinko N. Development of neutralizing antibodies against the three types of poliomyelitis virus during an epidemic period. American foumal of Hygiene 1953.58:207-22.

20 Nathanson N, Martin JR. The epidemiology of poliomyelitis: enigmas surrounding its appearance, epidemicity, and disappearance. Am $\mathcal{f}$ Epidemiol 1979;110:672-92.

21 Spicer CC. The incidence of poliomyelitis virus in normal children aged 0-5 years. $f \mathrm{Hyg}$ (Camb) 1961;59:143-59.

22 Hovi T, Huovilainen A, Kuronen T, $\boldsymbol{e}$ al. Outbreak of paralytic poliomyelitis in Finland: widespread circulation of antigenically altered poliovirus type 3 in a vaccinated population. Lancet 1986; i: 1427-32.

23 World Health Organisation. Imported case of poliomyelitis. Implications for travellers to endemic countries. Weekly Epidemiological Record 1986;61:372.

24 Cossar JH, Dewar RD, Fallon RJ, et al. Rapid response health surveillance of Scottish tourists. Travel and Traffic Medicine International 1984;2:23-7.

25 Grist NR, Cossar JH, Reid D, et al. Illness associated with a package holiday in Romania. Scott Med f 1985;30:156-60.

(Accepted 7 May 1987)

\begin{abstract}
Circulating antibodies to poliovirus were estimated in a group of 300 British and 84 foreign first year students who registered at the health centre of Nottingham University in 1984. Detectable antibodies to all three poliovirus serotypes were found in $\mathbf{2 1 2}$ (71\%) of the British students but in only $47(56 \%)$ of those from abroad. Most of the British students $(280 ; 93 \%)$ had been born in 1965 or 1966, when uptake of poliomyelitis vaccine was declining.

PHLS Communicable Disease Surveillance Centre, London NW9 5EQ

CAROL A JOSEPH, MSC, senior information officer

NORMAN T BEGG, DTM\&H, MFCM, senior registrar in community medicine

Bristol and Western Health Authority, Bristol BS1 3NP

ROSALIND E STANWELL-SMITH, MRCOG, MFCM, medical officer for environmental health

National Institute for Biological Standards and Control, Potters Bar, Hertfordshire EN6 3QG

DAVID I MAGRATH, BA, PHD, senior scientist

Correspondence and requests for reprints to: Carol Joseph.
\end{abstract}

Immunisation histories showed that 10 British and 29 foreign students ( $3 \%$ and $35 \%$ ) had no record of any immunisation; only five British and two foreign students, however, were negative for all three poliovirus serotypes.

These findings provide evidence that a high proportion of British born people aged 18-29 have adequate circulating poliovirus antibodies despite incomplete immunisation schedules. Though this is reassuring, the absence of antibodies in some students and the lack of previous immunisation against poliomyelitis in 39 suggest that reinforcing doses of vaccine at the time of leaving school or beginning further education are still warranted, particularly for students from other countries. The findings also emphasise the need for accurate immunisation records.

\section{Introduction}

A survey of the antibody state of newly registering students at Nottingham University has been carried out every year by the Public Health Laboratory Service since 1969. Antibodies to rubella 